\title{
No-tillage and crop-livestock with silage production impact little on carbon and nitrogen in the short-term in a subtropical Ferralsol
}

\author{
Jonatas Thiago Piva ${ }^{1} \oplus$, Jeferson Dieckow ${ }^{2} \oplus$ Cimélio Bayer $^{3} \oplus$, Maico Pergher $^{4} \oplus$, \\ Márcio Amaral Alburquerque ${ }^{5}$, Anibal de Moraes $^{2} \odot$, Volnei Pauletti² ${ }^{\circledR}$

\footnotetext{
1 Universidade Tecnológica Federal do Paraná, Santa Helena, PR, Brasil. E-mail: jonatas@utfpr.edu.br

2 Universidade Federal do Paraná, Curitiba, PR, Brasil. E-mail: jefersondieckow@ufpr.br; anibalm@ufpr.br; vpauletti@ufpr.br

${ }_{3}^{3}$ Universidade Federal do Rio Grande do Sul, Porto Alegre, RS, Brasil. E-mail: cimelio.bayer@ufrgs.br

${ }^{4}$ Empresa de Pesquisa Agropecuária e Extensão Rural de Santa Catarina, Florianópolis, SC, Brasil. E-mail:maicopergher@gmail.com

${ }^{5}$ Secretaria da Agricultura Pecuária e Agronegócio, Porto Alegre, RS, Brasil. E-mail: marcio-albuquerque@agricultura.rs.gov.br
}

ABSTRACT: We assessed the short-term (3.5 years) contributions of no-tillage (NT) relative to conventional tillage (CT), and of integrated crop-livestock systems combined with no-tillage (ICL-NT) relative to NT, on soil carbon (C) and nitrogen (N) and their physical fractions (free-light, occluded-light and heavy), in condition of maize silage production. An Umbric Ferralsol (Latossolo Bruno) was cultivated with ryegrass (Lolium multiflorum), for cover-crop in CT and NT, pasture in ICL-NT; and maize for silage. Notillage, relative to $\mathrm{CT}$, improved $\mathrm{C}$ and $\mathrm{N}$ stocks in $0-5 \mathrm{~cm}$ and mainly in the heavy fraction, but not deeper, so that stocks in whole 0-20 cm were (statistically) similar in both systems ( 67 Mg Cha-1 and $\left.\sim 4.8 \mathrm{Mg} \mathrm{N} \mathrm{ha}^{-1}\right)$. Likewise, the ICL-NT did not affect C and $\mathrm{N}$ stocks to $20 \mathrm{~cm}$ relative to NT, not even in the top layer or in some physical fraction. The short 3.5-year period, the originally high $\mathrm{C}$ and $\mathrm{N}$ contents of this Umbric Ferralsol and the removal of silage have possibly limited the effects of NT or ICL-NT. However, the adoption of those two conservation systems have at least no adverse effects on $\mathrm{C}$ and $\mathrm{N}$ stocks, without detriment to their already known productive and economic benefits.

Key words: carbon sequestration; conservationist agriculture; densimetric fractionation; soil organic matter

\section{Plantio direto e lavoura-pecuária com produção de silagem tem pouco impacto no carbono e nitrogênio no curto prazo em um Latossolo subtropical}

RESUMO: Foram avaliadas as contribuições de curto prazo (3,5 anos) do plantio direto (PD) em relação ao preparo convencional (PC) e da integração lavoura-pecuária sob PD (ILP-PD) em relação à lavoura contínua em PD sobre os estoques de carbono (C) e nitrogênio ( $N$ ) do solo e frações físicas (leve livre, leve oclusa e pesada), em condições de produção de milho para silagem. Um Latossolo Bruno foi cultivado com azevém (Lolium multiflorum) no inverno, para cobertura em PD e PC pastagem em ILP-PD, e milho para silagem no verão. $\mathrm{O}$ solo sob $\mathrm{PD}$, em relação ao $\mathrm{PC}$, melhorou os estoques de $\mathrm{C}$ e $\mathrm{N}$ na camada de 0-5 cm e principalmente na fração pesada, mas não em profundidade, de modo que os estoques na camada de $0-20 \mathrm{~cm}$

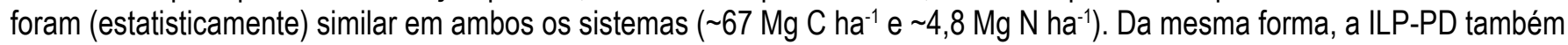
não alterou os estoques de $\mathrm{C}$ e $\mathrm{N}$ do solo até $20 \mathrm{~cm}$ em relação ao $\mathrm{PD}$, e nem mesmo na camada superior ou em alguma das frações físicas. $\mathrm{O}$ curto período de 3,5 anos, e os conteúdos originalmente elevados de $\mathrm{C}$ e $\mathrm{N}$ deste Latossolo Bruno e a remoção da fitomassa para silagem, possivelmente limitaram os efeitos do PD ou ILP-PD. No entanto, a adoção desses dois sistemas conservacionistas não teve nenhum efeito prejudicial nos estoques de $\mathrm{C}$ e $\mathrm{N}$, sem prejuízo aos seus já conhecidos benefícios produtivos e econômicos.

Palavras-chave: sequestro de carbono; agricultura conservacionista; fracionamento densimétrico; matéria orgânica do solo 


\section{Introduction}

The less oxidative soil environment under no-tillage (NT) may promote organic matter (OM) accumulation and, consequently, improvements in soil quality (Laroca et al., 2018). The annual rates of carbon (C) accumulation in the 0 to $20 \mathrm{~cm}$ of soil under NT vary from almost zero to approximately $1 \mathrm{Mg} \mathrm{C} \mathrm{ha}^{-1} \mathrm{yr}^{-1}$, with an average rate of $0.48 \mathrm{Mg} \mathrm{C} \mathrm{ha}^{-1} \mathrm{yr}^{-1}$ in the subtropical Southern Brazil (Bayer et al., 2006b).

Nevertheless, soil C and nitrogen (N) accumulation, improvement in soil quality and crop yields with NT are closely dependent on crop rotation plans that support adequate shoot and root residue input, both in winter and summer seasons. In this respect, winter fallow and or the cultivation of low-input cash or cover crops may reduce or even make null the rates of soil $\mathrm{C}$ and $\mathrm{N}$ accumulation, leading some authors to contest the potential of NT soil to serve as C or N sink (Haddaway et al., 2017).

The combination of NT crop production with livestock production through the integrated crop-livestock system $(\mathrm{ICL})$ is a further and important step towards conservationist agriculture, with environmental and productive benefits being reported (Carvalho et al., 2018). With adequate grazing, pasture net primary production may be even higher compared with no grazing, as observed in black oat or ryegrass (Sandini et al., 2011) and in brachiaria pastures (Debiasi \& Franchini, 2012). Despite that, there are divergent results in studies on the contribution of $\mathrm{ICL}$ to soil $\mathrm{C}$ and $\mathrm{N}$ storage. Some studies present increase in C stocks with ICL (Salton et al., 2011), while others present its maintenance (Salvo et al., 2010; Franzluebbers \& Stuedemann, 2013) or even depletion (George et al., 2013).

Progress on understanding the impacts of soil use and tillage systems on soil quality and OM accumulation and stabilization have been obtained by physical fraction approaches, which allows the isolation and quantification of structurally and functionally distinct compartments of the OM (Christensen, 2001). Densimetric fractionation allows the separation of three fractions: the free light (FL) fraction, which consists of inter-aggregate particulate OM (not protected); the occluded light (OL) fraction, which consists of intra-aggregate particulate OM (physically protected); and the heavy fraction, which consists of humified $\mathrm{OM}$ interacting with mineral surfaces via organo-mineral associations (Christensen, 2001). The light fractions, due to their particulate inherent features and fast turnover rates, are supposedly the most sensitive fraction to soil use and tillage systems, and so might be very useful in the assessment of short-term effects that those systems cause or will cause on soil OM of the soil (Conceição et al., 2008).

The Campos Gerais region of Paraná State, where the Brazilian NT has one of its birthplaces, is also a major milk producer of the country. One of the common soil use systems adopted in crop-dairy farms of the region is based on winter ryegrass for grazing and summer maize for silage, characterizing a sort of ICL system. That raises the question: how this soil use system with aboveground biomass removal with silage and grazing affects $\mathrm{C}$ and $\mathrm{N}$ stocks of the whole soil and its physical fractions, even under the conservationist NT management? Taking into account this question related to a particular condition of NT and ICL-NT, and the divergent results among studies related to $\mathrm{ICL}$ and soil $\mathrm{OM}$, we noticed a need for additional information about effects of NT and ICL on soil $\mathrm{C}$ and $\mathrm{N}$ stocks.

The hypothesis of this study is that, in the short term and under removal of the aboveground maize for silage, the conservationist management systems of NT, relative to $\mathrm{CT}$, and ICL-NT, relative to NT, have little impact to improve the whole $\mathrm{C}$ and $\mathrm{N}$ stocks of subtropical Umbric Ferralsol (Latossolo Bruno); yet, they do increment the stocks in the light (particulate) fractions, which are probably more sensitive to soil management changes than the heavy (humified) fraction. Therefore, our objective was to evaluate the short-term (3.5 years) impact of NT and ICL-NT conservationist systems with maize growing for silage on $\mathrm{C}$ and $\mathrm{N}$ stocks of a subtropical Umbric Ferralsol and its physical fractions.

\section{Materials and Methods}

\section{Field experiment}

The study was conducted in a field experiment initiated in the winter of 2005, at the experimental station of the $A B C$ Foundation, in Castro-PR, Brazil (24ㅇ 47' 53" S, 49은 42" W, and $996 \mathrm{~m}$ of altitude). The soil was a clayey Umbric Ferralsol (Latossolo Bruno) according to a local survey, with $439 \mathrm{~g} \mathrm{~kg}^{-1}$ clay, $177 \mathrm{~g} \mathrm{~kg}^{-1}$ silt, and $384 \mathrm{~g} \mathrm{~kg}^{-1}$ sand. The slope was less than $5 \%$. Climate was humid subtropical, Cfb (Köppen), with average monthly temperature varying from 12.5 oC (July) to 20.6 ㅇ (February), and with average annual precipitation of $1.656 \mathrm{~mm}$. The local native vegetation was short grassland named "Campos Gerais", which in the 1960s was converted into annual cropland based on conventional tillage, with disc plowing, a management system that lasted until no-tillage was adopted at the experiment establishment in 2005.

The experiment comprised three soil use systems and seven tillage system, and was cultivated with annual ryegrass (Lolium multiflorum L.) in winter and maize (Zea mays L.) for silage in summer. Maize was harvested at the R5.5 growth stage, at a cutting height of $10-15 \mathrm{~cm}$. The ryegrass sowing in a row, with a seeder, with a spacing of $17 \mathrm{~cm}$ and density of $100 \mathrm{~kg} \mathrm{ha}^{-1}$ of seed, usually in the month of April. Three combinations of soil use and tillage systems were selected and evaluated in this study: two where ryegrass was used as winter cover crop and soil was subjected either to conventional tillage (CT) or no-tillage (NT); and a third system where ryegrass was cattle-grazed, corresponding to the integrated crop-livestock combined with no-tillage (ICL-NT). Therefore, the treatments were as follows: (i) conventional tillage (CT) with ryegrass for coverage; (ii) no-tillage (NT) with ryegrass for coverage; (iii) integrated crop-livestock under notillage (ICL-NT). The choice of these treatments is due to the fact that NT or ICL-NT is widely used in farms of the region; 
and CT served as a control treatment. The experiment was arranged in a complete randomized block design with four replicates. In CT, operations included one a heavy disc harrow up to approximately $15 \mathrm{~cm}$ depth followed by two leveling disc harrow up to approximately $10 \mathrm{~cm}$ depth; and they were carried out twice a year, in autumn, before ryegrass sowing, and in spring, before maize seeding. In NT, ryegrass was desiccated with glyphosate herbicide at its flowering stage, in the spring. In ICL-NT, ryegrass was grazed by Jersey or Holstein heifers (10-18 months old), in three or four grazing cycles per season, each cycle starting when ryegrass was $25 \mathrm{~cm}$ high and finishing two or three days later when ryegrass was lowered to $10 \mathrm{~cm}$ high, whit a variable stocking rate. The lasting ryegrass residue after the last grazing cycle of the season was desiccated with glyphosate herbicide.

Data of aboveground biomass production and addition of ryegrass were obtained in the archives of the experiment; while aboveground biomass addition of maize was assumed as zero, considering the biomass was exported for silage. For ryegrass in ICL-NT, the biomass addition was that of dung, and assumed as being $30 \%$ of the produced biomass, considering a digestibility of 70\% (Miguel et al., 2012).

\section{Soil sampling, physical fractionation and $\mathrm{C}$ and $\mathrm{N}$ analysis}

Soil samples of the $0-5,5-10$ and $10-20 \mathrm{~cm}$ layers were collected in December 2008, when the experiment was 3.5 years old. Samples were collected with spatula in two pits 20 $\mathrm{cm}$ wide and $40 \mathrm{~cm}$ long located in the central region of each plot of $10 \times 10 \mathrm{~m}$. Two sub-samples were obtained in each pit, four per plot. After air-drying, samples were ground to $\leq 2 \mathrm{~mm}$ and an aliquot was further ground to $\leq 250 \mu \mathrm{m}$ to be analyzed for $\mathrm{C}$ and $\mathrm{N}$ by dry combustion (Elementar Vario EL Analyzer).

Soil samples were subjected to density fractionation to obtain the free light (FL), occluded light (OL) and heavy fractions of OM, using a method adapted from Conceição et al. (2008). In a $100 \mathrm{~mL}$ centrifuge tube containing $20 \mathrm{~g}$ of soil ( $\leq 2 \mathrm{~mm}$ ) we added $60 \mathrm{~mL}$ of sodium polytungstate solution adjusted to a density of $2.0 \mathrm{Mg} \mathrm{m}^{-3}$. Each tube was sealed with a rubber stopper and manually and slowly inverted five times, so that the FL fraction could be released from between the soil aggregates. After centrifugation (90 min, $2000 \times g$ ), the supernatant was vacuum filtered and the FL fraction retained in the glass fiber filter (Whatman GF/C) was washed with distilled water to remove the excess sodium polytungstate and then dried at 60 ${ }^{\circ} \mathrm{C}$. To obtain the $\mathrm{OL}$ fraction, the tube was refilled with $60 \mathrm{~mL}$ of sodium polytungstate solution, the soil pellet was dispersed by ultrasonic energy (410 $\mathrm{J} \mathrm{mL}^{-1}$, previous test was carried out) and the suspension centrifuged ( $90 \mathrm{~min}, 2000 \times \mathrm{g}$ ). The $\mathrm{OL}$ fraction in the supernatant was recovered by filtering and washing, as described for the FL fraction. After being weighed, the FL and $\mathrm{OL}$ fractions were ground to $\leq 250 \mu \mathrm{m}$ and analyzed for $\mathrm{C}$ and $\mathrm{N}$ by dry combustion (Elementar Vario EL Analyzer). The $\mathrm{C}$ concentration of the heavy fraction was assumed as being the difference between the $C$ concentration in the whole soil sample and the $\mathrm{C}$ concentration in the $\mathrm{FL}$ plus $\mathrm{OL}$ fractions (all in $\mathrm{g} \mathrm{kg}^{-1}$ of soil). Same approach was used for $\mathrm{N}$ concentration.
The $\mathrm{C}$ and $\mathrm{N}$ stocks in the whole soil sample and in physical fractions were calculated according to the equivalent soil mass approach (Alburquerque et al., 2015), considering the mass of the CT soil as reference. The mass of soil was calculated for each layer taking into account its bulk density, which was measured with a metal cylinder ( $\varnothing 56.3 \mathrm{~mm}$; h $29.8 \mathrm{~mm}$ ) placed vertically in the middle of each layer, according to the core method (Embrapa, 2011).

The annual $\mathrm{C}$ and $\mathrm{N}$ accumulation rates over the 3.5 years of the experiment was calculated for NT, relative to $\mathrm{CT}$, and for ICL-NT, relative to NT. This is referred to as the relative sequestration rate rather than the absolute sequestration rate because it does not consider the $\mathrm{OC}$ stock at the beginning of the experiment, information on which was not available; according to the equations below, as exemplified for $\mathrm{C}$ (Equations 1 and 2).

$\mathrm{C}$ accumulation rate in $\mathrm{NT}=\frac{(\text { soil } \mathrm{C} \text { stock in } \mathrm{NT})-(\text { soil } \mathrm{C} \text { stock in } \mathrm{CT})}{3.5 \mathrm{yr}}$

C accumulation rate in ICL-NT $=\frac{\text { (soil C stock in ICL-NT })-(\text { soil C stock in NT })}{3.5 \mathrm{yr}}$

where: $\mathrm{C}$ accumulation rate in NT $\left(\mathrm{Mg} \mathrm{ha}^{-1} \mathrm{yr}^{-1}\right)$; soil $\mathrm{C}$ stock in $\mathrm{NT}$, soil $\mathrm{C}$ stock in $\mathrm{CT}$ and soil $\mathrm{C}$ stock in ICL-NT (Mg ha-1).

\section{Statistical analysis}

Data were submitted to analysis of variance and the means were compared by the Tukey test ( $p \leq 0.10)$; according to the complete randomized block design of the field experiment, through the statistical program Statistica 7.0 (Statsoft, 2007).

\section{Results and Discussion}

No-tillage improved $\mathrm{C}$ and $\mathrm{N}$ concentrations and stocks relative to $\mathrm{CT}$, but that improvement was restricted only to the first $5 \mathrm{~cm}$ of soil (Tables 1 and 2). In that layer, NT accumulated $0.61 \mathrm{Mg} \mathrm{Cha}^{-1} \mathrm{yr}^{-1}$ and $0.06 \mathrm{Mg} \mathrm{N} \mathrm{ha}^{-1} \mathrm{yr}^{-1}$, relative to CT (Table 2).

Nearly all the accumulation from $\mathrm{C}$ and $\mathrm{N}$ occurred in the heavy fraction (0.59 $\mathrm{Mg} \mathrm{C}^{-1} \mathrm{yr}^{-1}$ and $0.05 \mathrm{Mg} \mathrm{N}^{-1}$ $\mathrm{yr}^{-1}$ ), but not in the light fractions ( $\mathrm{FL}$ and $\mathrm{OL}$ ), where stocks remained similar in NT and CT (Table 2). The fact that $\mathrm{C}$ and $\mathrm{N}$ accumulated in the heavy fraction but not significantly in the light fractions is intriguing and contradicts our hypothesis that such accumulation in short-term conservation systems takes place in the light (particulate) fractions, which are supposedly more sensitive to soil management changes than the heavy (humified) fraction. One explanation to this contradictory result could be that at soil sampling, 70-75 days after ryegrass desiccation and during maize vegetative growth, much of the light fraction derived from the latest biomass residue input (ryegrass desiccation) was decomposed and partially incorporated and accumulated into the increasing $\mathrm{C}$ and $\mathrm{N}$ pools of the heavy fraction of NT soil. Thus, no difference for the light fraction level between NT and CT. Thus, some studies 
Table 1. Carbon (C) and nitrogen $(\mathrm{N})$ concentrations and $\mathrm{C}: \mathrm{N}$ ratio of a subtropical Umbric Ferralsol (Latossolo Bruno) and its physical fractions (FL, free-light; OL, ocluded-light; and heavy) subjected to conventional tillage (CT), no-tillage (NT) or integrated-crop livestock under no-tillage (ICL-NT). Castro-PR, Brazil.

\begin{tabular}{|c|c|c|c|c|c|c|c|c|c|c|c|c|c|c|c|c|}
\hline & \multicolumn{4}{|c|}{$C\left(\mathrm{~g} \mathrm{~kg}^{-1}\right)$} & \multicolumn{4}{|c|}{$\mathrm{N}\left(\mathrm{g} \mathrm{kg}^{-1}\right)$} & \multicolumn{4}{|c|}{ C:N ratio } & \multicolumn{3}{|c|}{ Fraction mass:soil mas } & \multirow{2}{*}{$\begin{array}{l}\text { Bulk density } \\
\left(\mathrm{Mg} \mathrm{m}^{-3}\right)\end{array}$} \\
\hline & Soil & $\mathrm{FL}$ & $\mathrm{OL}$ & Heavy & Soil & FL & $\mathrm{OL}$ & Heavy & Soil & FL & $\mathrm{OL}$ & Heavy & FL & $\mathrm{OL}$ & Heavy & \\
\hline \multicolumn{17}{|c|}{$0-5 \mathrm{~cm}$} \\
\hline CT & $31.0 \mathrm{~b}$ & $87.4 \mathrm{a}$ & $90.2 \mathrm{a}$ & $27.4 \mathrm{~b}$ & $2.30 \mathrm{~b}$ & $5.03 \mathrm{a}$ & $5.81 \mathrm{a}$ & $2.11 \mathrm{~b}$ & $13.5 \mathrm{a}$ & $17.4 \mathrm{a}$ & $15.5 \mathrm{a}$ & $13.0 \mathrm{a}$ & 0.027 a & $0.031 \mathrm{a}$ & $0.942 a$ & $1.09 \mathrm{a}$ \\
\hline ICL-NT & $35.5 \mathrm{a}$ & $71.5 b$ & $73.4 \mathrm{a}$ & $32.9 \mathrm{a}$ & $2.82 \mathrm{a}$ & $4.75 \mathrm{a}$ & $5.27 \mathrm{a}$ & $2.66 \mathrm{a}$ & $12.6 \mathrm{~b}$ & $15.1 b$ & $13.9 \mathrm{~b}$ & $12.4 \mathrm{a}$ & $0.028 \mathrm{a}$ & $0.037 \mathrm{a}$ & $0.935 \mathrm{a}$ & $1.16 \mathrm{a}$ \\
\hline \multicolumn{17}{|c|}{$5-10 \mathrm{~cm}$} \\
\hline CT & $29.2 \mathrm{a}$ & $68.1 \mathrm{a}$ & $125.0 \mathrm{a}$ & $26.7 \mathrm{a}$ & $2.22 \mathrm{a}$ & $4.37 \mathrm{a}$ & $8.95 a$ & $2.06 \mathrm{a}$ & $13.1 b$ & $15.6 \mathrm{a}$ & $14.0 \mathrm{~b}$ & $13.0 \mathrm{~b}$ & $0.020 \mathrm{a}$ & 0.017 a & $0.963 a$ & $1.20 \mathrm{a}$ \\
\hline \multicolumn{17}{|c|}{$10-20 \mathrm{~cm}$} \\
\hline CT & $26.7 \mathrm{a}$ & $55.3 \mathrm{a}$ & $119.4 \mathrm{a}$ & $25.4 \mathrm{a}$ & $1.78 \mathrm{a}$ & $3.25 \mathrm{a}$ & $6.76 \mathrm{a}$ & $1.71 \mathrm{a}$ & $15.0 \mathrm{a}$ & $17.0 \mathrm{~b}$ & $17.7 \mathrm{~b}$ & $14.8 \mathrm{a}$ & 0.008 a & $0.011 \mathrm{a}$ & 0.981 a & $1.22 \mathrm{a}$ \\
\hline NT & $25.4 \mathrm{a}$ & $68.5 \mathrm{a}$ & 73.1 b & $24.8 \mathrm{a}$ & $1.71 \mathrm{a}$ & $3.64 \mathrm{a}$ & 3.74 b & $1.68 \mathrm{a}$ & 14.9 a & $18.8 \mathrm{a}$ & $19.5 \mathrm{a}$ & $14.7 \mathrm{a}$ & 0.002 a & $0.011 \mathrm{a}$ & $0.987 a$ & $1.24 \mathrm{a}$ \\
\hline ICL-NT & $25.8 \mathrm{a}$ & $46.3 a$ & $87.2 \mathrm{~b}$ & $24.8 \mathrm{a}$ & $1.68 \mathrm{a}$ & $2.92 \mathrm{a}$ & $4.94 a b$ & $1.63 \mathrm{a}$ & $15.4 \mathrm{a}$ & $15.9 \mathrm{~b}$ & $17.7 \mathrm{~b}$ & $15.3 \mathrm{a}$ & $0.006 a$ & $0.014 a$ & $0.980 a$ & $1.17 \mathrm{a}$ \\
\hline
\end{tabular}

Means followed by the same letter, in the same column and soil layer, do not differ significantly according to the Tukey test $(p \geq 0.10)$.

Table 2. Carbon (C) and nitrogen (N) stocks and annual accumulation rates $(\Delta C$ and $\Delta N$ ) of a subtropical Umbric Ferralsol (Latossolo Bruno) and its physical fractions (FL, free-light; OL, ocluded-light; and heavy) subjected to conventional tillage (CT), no-tillage (NT) or integrated-crop livestock under no-tillage (ICL-NT). Castro-PR, Brazil.

\begin{tabular}{|c|c|c|c|c|c|c|c|c|}
\hline & Soil & $\overline{F L}$ & $\overline{\mathrm{OL}}$ & Heavy & Soil & $\overline{F L}$ & $\overline{\mathrm{OL}}$ & Heavy \\
\hline & \multicolumn{4}{|c|}{$\mathrm{C}\left(\mathrm{Mg} \mathrm{ha}^{-1}\right)$} & \multicolumn{4}{|c|}{$\mathrm{N}\left(\mathrm{Mg} \mathrm{ha}^{-1}\right)$} \\
\hline \multicolumn{9}{|c|}{$0-5 \mathrm{~cm}$} \\
\hline CT & $16.90 \mathrm{~b}$ & 1.29 a [8] & 1.52 a [9] & 14.09 b [83] & $1.25 \mathrm{~b}$ & 0.07 a [6] & $0.10 \mathrm{a}[8]$ & $1.08 \mathrm{~b}[86]$ \\
\hline NT & $19.03 \mathrm{a}$ & 0.99 a [5] & $1.90 \mathrm{a}[10]$ & 16.14 a [85] & $1.46 \mathrm{a}$ & 0.07 a [5] & $0.13 \mathrm{a}$ [9] & 1.26 a [86] \\
\hline ICL-NT & $19.34 \mathrm{a}$ & 1.08 a [6] & $1.48 \mathrm{a}[8]$ & 16.78 a [86] & $1.54 \mathrm{a}$ & 0.07 a [5] & $0.11 \mathrm{a}[7]$ & 1.36 a [88] \\
\hline \multicolumn{9}{|c|}{$5-10 \mathrm{~cm}$} \\
\hline CT & $17.51 \mathrm{a}$ & 0.82 a [5] & 1.28 a [7] & 15.41 a [88] & $1.33 \mathrm{a}$ & 0.05 a [4] & 0.09 a [7] & 1.19 a [89] \\
\hline NT & $16.87 \mathrm{a}$ & 0.38 a [2] & 1.29 a [8] & 15.20 a $[90]$ & $1.29 \mathrm{a}$ & 0.02 a [2] & $0.08 \mathrm{a}[6]$ & 1.19 a [92] \\
\hline ICL-NT & $16.91 \mathrm{a}$ & 0.97 a [6] & $0.93 \mathrm{a}[5]$ & 15.01 a [89] & $1.22 \mathrm{a}$ & 0.07 a [6] & $0.06 \mathrm{a}[5]$ & 1.09 a [89] \\
\hline \multicolumn{9}{|c|}{$10-20 \mathrm{~cm}$} \\
\hline CT & $32.52 \mathrm{a}$ & 0.54 a [2] & 1.60 a [5] & 30.38 a [93] & $2.17 a$ & 0.03 a [1] & 0.09 a [4] & 2.05 a [95] \\
\hline NT & $31.13 \mathrm{a}$ & 0.19 a [1] & 1.05 a [3] & 29.89 a [96] & $2.11 \mathrm{a}$ & 0.01 a [0] & $0.05 \mathrm{a}$ [3] & 2.05 a [97] \\
\hline ICL-NT & $31.56 \mathrm{a}$ & $0.37 \mathrm{a}[1]$ & $1.50 \mathrm{a}$ [5] & 29.69 a [94] & $2.06 \mathrm{a}$ & $0.02 \mathrm{a}$ [1] & $0.09 \mathrm{a}$ [4] & 1.95 a [95] \\
\hline \multicolumn{9}{|c|}{$0-20 \mathrm{~cm}$} \\
\hline CT & $66.93 a$ & 2.64 a [4] & 4.40 a [7] & 59.89 а [89] & $4.76 \mathrm{a}$ & 0.16 a [3] & $0.28 \mathrm{a}[6]$ & 4.32 a [91] \\
\hline NT & $67.03 a$ & 1.56 a [2] & 4.24 a [6] & 61.23 a [91] & $4.86 \mathrm{a}$ & 0.10 a [2] & $0.27 \mathrm{a}[6]$ & 4.49 a [92] \\
\hline ICL-NT & $67.81 \mathrm{a}$ & 2.42 a [3] & 3.91 a [6] & 61.48 a [91] & $4.82 \mathrm{a}$ & 0.16 a [3] & $0.26 \mathrm{a}$ [5] & 4.40 a [91] \\
\hline \multicolumn{5}{|c|}{$\Delta C\left(\mathrm{Mg} \mathrm{ha}^{-1} \mathrm{yr}^{-1}\right)$} & \multicolumn{4}{|c|}{$\Delta \mathrm{N}\left(\mathrm{Mg} \mathrm{ha}^{-1} \mathrm{yr}^{-1}\right)$} \\
\hline \multicolumn{9}{|c|}{$0-5 \mathrm{~cm}$} \\
\hline NT & $0.61 *$ & $-0.09 \mathrm{~ns}$ & $0.11 \mathrm{~ns}$ & $0.59 *$ & $0.06 *$ & $0.00 \mathrm{~ns}$ & $0.01 \mathrm{~ns}$ & $0.05 *$ \\
\hline ICL-NT & $0.09 \mathrm{~ns}$ & $0.03 \mathrm{~ns}$ & $-0.12 \mathrm{~ns}$ & $0.18 \mathrm{~ns}$ & $0.02 \mathrm{~ns}$ & $0.00 \mathrm{~ns}$ & $-0.01 \mathrm{~ns}$ & $0.03 \mathrm{~ns}$ \\
\hline \multicolumn{9}{|c|}{$5-10 \mathrm{~cm}$} \\
\hline NT & $-0.18 \mathrm{~ns}$ & $-0.12 \mathrm{~ns}$ & $0.00 \mathrm{~ns}$ & $-0.06 \mathrm{~ns}$ & $-0.01 \mathrm{~ns}$ & $-0.01 \mathrm{~ns}$ & $0.00 \mathrm{~ns}$ & $0.00 \mathrm{~ns}$ \\
\hline ICL-NT & $0.01 \mathrm{~ns}$ & $0.16 \mathrm{~ns}$ & $-0.10 \mathrm{~ns}$ & $-0.05 \mathrm{~ns}$ & $-0.02 n s$ & $0.01 \mathrm{~ns}$ & $0.00 \mathrm{~ns}$ & $-0.03 \mathrm{~ns}$ \\
\hline \multicolumn{9}{|c|}{$10-20 \mathrm{~cm}$} \\
\hline NT & $-0.40 \mathrm{~ns}$ & $-0.10 \mathrm{~ns}$ & $-0.16 \mathrm{~ns}$ & $-0.14 n s$ & $-0.02 n s$ & $-0.01 \mathrm{~ns}$ & $-0.01 \mathrm{~ns}$ & $0.00 \mathrm{~ns}$ \\
\hline ICL-NT & $0.12 \mathrm{~ns}$ & $0.05 \mathrm{~ns}$ & $0.12 \mathrm{~ns}$ & -0.05 ns & $-0.01 \mathrm{~ns}$ & $0.00 \mathrm{~ns}$ & $0.01 \mathrm{~ns}$ & $-0.02 n s$ \\
\hline \multicolumn{9}{|c|}{$0-20 \mathrm{~cm}$} \\
\hline NT & $0.03 \mathrm{~ns}$ & $-0.31 \mathrm{~ns}$ & $-0.04 \mathrm{~ns}$ & $0.39 \mathrm{~ns}$ & $0.03 \mathrm{~ns}$ & $-0.02 \mathrm{~ns}$ & $0.00 \mathrm{~ns}$ & $0.05 \mathrm{~ns}$ \\
\hline ICL-NT & $0.22 \mathrm{~ns}$ & $0.24 \mathrm{~ns}$ & $-0.09 \mathrm{~ns}$ & $0.07 \mathrm{~ns}$ & $-0.01 \mathrm{~ns}$ & $0.02 \mathrm{~ns}$ & $0.00 \mathrm{~ns}$ & $-0.03 \mathrm{~ns}$ \\
\hline
\end{tabular}

Means followed by the same letter, in the same column and soil layer, do not differ significantly according to the Tukey test $(p \geq 0.10)$.

Value in brackets denotes the percentage relative to the total $\mathrm{C}$ or $\mathrm{N}$ stocks.

Annual accumulation rates $(\Delta \mathrm{C}$ or $\Delta \mathrm{N})$ are significant $\left(^{*}\right)$ or not significant $(\mathrm{ns})$ according to the Tukey test $(p<0.10 ; p \geq 0.10)$. Accumulation rates for NT were calculated relative to $\mathrm{CT}$, and for ICL-NT they were calculated relative to NT; considering the 3.5-year age of the experiment.

show that there is a higher rate of decomposition of residues and release of nutrients in the first 15 days, and close to 75 days, approximately $50 \%$ of the material, has already been decomposed and incorporated into the soil (Aita \& Giacomini, 2003; Medrado et al., 2011).
Since $C$ and $N$ accumulations were not observed in the 5-10 and $10-20 \mathrm{~cm}$ layers, the incremental effect of the $0-5 \mathrm{~cm}$ was not noticed in the whole $0-20 \mathrm{~cm}$ layer, so that no differences occurred between NT and CT for $\mathrm{C}$ and $\mathrm{N}$ stocks in this layer, and the corresponding $\mathrm{C}$ and $\mathrm{N}$ accumulation rates for NT 
became null (0.03 $\mathrm{Mg} \mathrm{C} \mathrm{ha}^{-1} \mathrm{yr}^{-1}$ and $0.03 \mathrm{Mg} \mathrm{N} \mathrm{ha}^{-1} \mathrm{yr}^{-1}$, not significant, Table 2). In the top $5 \mathrm{~cm}$ of NT soil, the minimum soil disturbance and therefore the maintenance of the surface and root residues were possibly the main driving factors of the significant $\mathrm{C}$ and $\mathrm{N}$ accumulations, a well-known process (Bayer \& Mielniczuk, 1997). However, the non-significant rates of $\mathrm{C}$ and $\mathrm{N}$ accumulation to the top $20 \mathrm{~cm}$ under NT differed from results of Bayer et al. (2000) and Sá et al. (2001), who also worked in subtropical Brazilian experiments but observed rates up to $0.81 \mathrm{MgCh} \mathrm{h}^{-1}$ in the first $20 \mathrm{~cm}$, using crop rotation and including legumes in the system, promoting greater $\mathrm{C}$ addition to the soil. Yet, compared to the 9 years of the experiment of Bayer et al. (2000), on an Acrisol (Argissolo Vermelho), and to the 22 years of that of Sá et al. (2001), on a Rhodic Ferralsol (Latossolo Vermelho), both without removal of crop aboveground residues, the field experiment of the current study differed from theirs on three main aspects: the young age, 3.5 years; the soil class, Umbric Ferralsol (Latossolo Bruno); and the removal of maize aboveground for silage.

In the current study, 3.5 years was not enough for NT to accumulate significant $\mathrm{C}$ and $\mathrm{N}$ stocks to $20 \mathrm{~cm}$. The originally high $C$ stock of this Umbric Ferralsol (> $65 \mathrm{Mg} \mathrm{C}^{-1}$ in the first $20 \mathrm{~cm}$, Table 2) might have also contributed to limit increments to $\mathrm{C}$ and $\mathrm{N}$, a supposition supported by Campbell et al. (1991), who found no OM response to 31 years of crop rotations in soil with high OM content (about $64 \mathrm{Mg} \mathrm{C}^{-1}$ in the top $15 \mathrm{~cm}$ ).

Nonetheless, the low biomass input due to maize removal for silage was also an important, if not the most important, cause of the lack of $C$ and $N$ accumulation in the $0-20 \mathrm{~cm}$ of NT soil. In both tillage systems, the overall aboveground dry matter yield averaged approximately $21 \mathrm{Mg} \mathrm{DM} \mathrm{ha}^{-1} \mathrm{yr}^{-1}$, which is quite high (4 of ryegrass and 17 of maize) (Table 3). But with silage removal, the effective aboveground input in the two tillage systems was only the about $4 \mathrm{Mg} \mathrm{DM} \mathrm{ha}^{-1} \mathrm{yr}^{-1}$ of ryegrass, which is surely little to improve $\mathrm{C}$ and $\mathrm{N}$ in subtropical NT soil (Bayer et al., 2006a; Assmann et al., 2014; Alburquerque et al., 2015). As reported by Ferreira et al. (2012), the minimal required maintaining SOC stocks; which in Brazilian subtropical clayey soils under NT, must be above 6.8 $\mathrm{Mg} \mathrm{DM} \mathrm{ha-1}^{-1} \mathrm{yr}^{-1}$.

Regarding to the ICL-NT, there was no effect of this system on soil $\mathrm{C}$ and $\mathrm{N}$ concentrations (Table 1 ) or stocks (Table 2) relative to NT system, not even in the $0-5 \mathrm{~cm}$. As discussed for tillage systems, it is likely that the relatively short 3.5-year experimental period, the originally high $\mathrm{C}$ and $\mathrm{N}$ contents of this Umbric Ferralsol, and the removal of the aboveground biomass of maize for silage have limited the responses of soil $\mathrm{C}$ and $\mathrm{N}$ to ICL-NT. In this system the aboveground biomass yield was $23.4 \mathrm{Mg} \mathrm{DM} \mathrm{ha}^{-1} \mathrm{yr}^{-1}$ (4.9 for grazed ryegrass and 18.4 for silage maize, Table 3 ). But, taking into account that maize was removed for silage and that ryegrass was grazed to have only about $30 \%$ of its biomass returned as dung pats [considering 70\% digestibility (Miguel et al., 2012)], the effective aboveground input was just the approximately 1.5 Mg DM ha-1 $\mathrm{yr}^{-1}$ as manure (Table 3). That was even lower than the aboveground input of about $4 \mathrm{Mg} \mathrm{DM} \mathrm{ha}^{-1} \mathrm{yr}^{-1}$ in NT. Yet, regardless of the very low aboveground input in ICL-NT, the soil $\mathrm{C}$ and $\mathrm{N}$ stocks were not depleted in ICL-NT relative to NT, but maintained. We argue that, in this ICL system with aboveground silage removal, roots are indeed playing the vital role of adding biomass to keep soil $\mathrm{C}$ and $\mathrm{N}$ levels. This argument is supported by studies that suggest that roots are indeed important $\mathrm{C}$ and $\mathrm{N}$ contributors to the soil $\mathrm{OM}$ pool, once they might interact closely with mineral surfaces, be physically protected within aggregates, and be more recalcitrant than the aboveground residue (Kong \& Six, 2010).

Other studies have also reported no changes in soil $\mathrm{C}$ and $\mathrm{N}$ stock in areas under ICL (Salvo et al., 2010; Franzluebbers \& Stuedemann, 2013). The cited studies and ours demonstrate that although not increasing soil $\mathrm{C}$ and $\mathrm{N}$ stocks, the adoption of ICL had at least no adverse effects on those stocks, without compromising the already known productive and economic advantages of this system.

Like in the whole soil, $\mathrm{C}$ and $\mathrm{N}$ stocks in physical fractions did not respond to ICL-NT, relative to NT, neither in fractions of the top $5 \mathrm{~cm}$. Once more, our hypothesis that short-term accumulation should take place in the light fractions was not confirmed. Part of the same explanation given for the lack of response of the light fractions to NT relative to CT can be used here, i.e. that soil sampling was too late relative to the latest biomass input (ryegrass desiccation), so that much of the light fraction derived from ryegrass, in this case ryegrass root, was already decomposed. Nonetheless, the lower aboveground input in ICL-NT (about 1.5 $\mathrm{Mg} \mathrm{DM} \mathrm{ha}^{-1}$ as dung) compared to that in NT (approximately $4 \mathrm{Mg} \mathrm{DM} \mathrm{ha}^{-1}$ as ryegrass) might also be an important reason for that lack of response in the light fractions.

Effects of ICL-NT on C and N stocks of physical fractions diverge between studies, just as the effects on total $\mathrm{C}$ and $\mathrm{N}$ stocks. Studies in the Brazilian or Uruguayan subtropics, including either annual or multi-year pasture cycles, report a decrease of the $\mathrm{C}$ stock in the particulate fraction with ICL-NT

Table 3. Production and addition of aboveground biomass of ryegrass and silage maize in a subtropical Umbric Ferralsol (Latossolo Bruno) subjected to conventional tillage (CT), no-tillage (NT) or integrated-crop livestock under no-tillage (ICL-NT). Castro-PR, Brazil.

\begin{tabular}{|c|c|c|c|c|c|c|}
\hline & \multicolumn{3}{|c|}{ Biomass production (Mg DM ha-1) } & \multicolumn{3}{|c|}{ Biomass addition (Mg DM ha-1) } \\
\hline & Ryegrass & Maize & Total & Ryegrass & Maize & Total \\
\hline $\mathrm{CT}$ & $3.94 \pm 1.54$ & $16.80 \pm 2.37$ & $20.75 \pm 5.30$ & $3.94 \pm 1.54$ & 0.0 & $3.94 \pm 1.54$ \\
\hline NT & $4.05 \pm 1.51$ & $17.42 \pm 1.91$ & $21.47 \pm 5.15$ & $4.05 \pm 1.51$ & 0.0 & $4.05 \pm 1.51$ \\
\hline
\end{tabular}

\pm standard deviation. 
(Assmann et al., 2015; Salvo et al., 2010). On the contrary, in a study in the Brazilian Cerrado and under multi-year cycles showed that ICL-NT increased the $C$ stock in that fraction (Salton et al., 2011). Such differences of results among studies just indicate that there is no standard or strict ICL system, with similar effects on soil, but systems sensitive to all sorts of environmental and anthropic influences that lead to distinct effects on soil OM, mainly due to the quantity of residues input and animal management.

With respect to the influence of physical fractions, regardless of soil use, tillage or layer, the OL fraction tended to store more $\mathrm{C}$ and $\mathrm{N}$ than the $\mathrm{FL}$, in short term (Table 2), possibly due to the physical protection (occlusion) offered in stable aggregates (Conceição et al., 2008; Reis et al., 2014). Compared to the heavy fraction, the light fractions had higher $\mathrm{C}$ and $\mathrm{N}$ concentrations and higher $\mathrm{C}: \mathrm{N}$ ratios (Table $1)$, what is consistent with the presence of particulate OM derived from plant residues in the light fractions and with the composition of the more humified and stable OM in the heavy fraction (Balabane \& Plante, 2004). The greater stability of $C$ and $\mathrm{N}$ in heavy fraction is mainly due to the organo-mineral associations resulting from ligand exchange bonding between the functional groups of OM (carboxylic and phenolic) and metals of the crystalline structure of minerals (Von Lützow et al., 2008). The importance of the heavy fraction as the principal $\mathrm{C}$ and $\mathrm{N}$ sink in subtropical soils under NT was already reported by Conceição et al. (2013), in agreement with the stabilization of the OM by organo-mineral association and microaggregate physical occlusion that occur in the heavy fraction (Balabane \& Plante, 2004).

However, some studies indicate that under certain conditions of climate and soil, stabilization of the particulate fraction of OM (labile fraction) associated with minerals can also occur (Reis et al., 2014; Salvo et al., 2010), mainly due to the greater capacity that clay soils under no-tillage has to perform organo-mineral interactions and sorption with these labile fractions, the effects being more pronounced in the soil surface $(0-3 \mathrm{~cm})$, diluting in the arable layer (Salvo et al., 2010).

\section{Conclusions}

Short-term (3.5-year) no-tillage had little effect on total $\mathrm{C}$ and $\mathrm{N}$ accrual of subtropical Umbric Ferralsol (Latossolo Bruno), relative to conventional tillage management; in system under removal of the aboveground maize for silage. Increments of $\mathrm{C}$ and $\mathrm{N}$ stocks were restricted only to the first $5 \mathrm{~cm}$ of soil and to the heavy fraction.

Under the same condition of silage removal, short-term integrated crop-livestock combined with no-tillage did not increase the soil $\mathrm{C}$ and $\mathrm{N}$ stocks, in any layer or fraction, relative to crop no-tillage; but did maintain them.

\section{Acknowledgements}

Authors are grateful to Conselho Nacional de
Desenvolvimento Científico e Tecnológico (CNPq) for

financially supporting the study and for granting scholarships; and to Fundação Araucária (FA/PR) for financial support. Contribution of field (Fundação $A B C$ ) and laboratory staff (UFPR) is also acknowledged.

\section{Literature Cited}

Aita, C.; Giacomini, S.J. Decomposição e liberação de nitrogênio de resíduos culturais de plantas de cobertura de solo solteiras e consorciadas. Revista Brasileira de Ciência do Solo, v. 27, n.4, p. 601-612, 2003. https://doi.org/10.1590/S010006832003000400004

Alburquerque, M.A.; Dieckow, J.; Sordi, A.; Piva, J.T.; Bayer, C.; Molin, R.; Pergher, M.; Ribeiro Junior, P.J. Carbon and nitrogen in a Ferralsol under zero-tillage rotations based on cover, cash or hay crops. Soil Use and Management, v. 31, n.1, p. 1-9, 2015. https:// doi.org/10.1111/sum.12173.

Assmann, J.M; Anghinoni, I.; Martins, A.P.; Costa, S.E.V.G. de A.; Cecagno, F.S.C.; Carvalho, P.C. De F. Soil carbon and nitrogen stocks and fractions in a long-term integrated crop-livestock system under no-tillage in southern Brazil. Agriculture, Ecosystems \& Environment, v. 190, p. 52-59, 2014. https://doi.org/10.1016/j. agee.2013.12.003.

Assmann, J.M; Anghinoni, I.; Martins, A.P.; Costa, S.E.V.G. de A.; Kunrath, T.R.; Bayer, C.; Carvalho, P.C. De F.; Franzluebbers, A.J. Carbon and nitrogen cycling in an integrated soybean-beef cattle production system under different grazing intensities. Pesquisa Agropecuária Brasileira, v. 50, n.10, p. 67-978, 2015. https://doi. org/10.1590/S0100-204X2015001000013.

Balabane, M.; Plante, A.F. Aggregation and carbon storage in silty soil using physical fractionation techniques. European Journal of Soil Science, v. 55, n.2, p. 415-427, 2004. https://doi.org/10.1111/ j.1351-0754.2004.0608.x.

Bayer, C.; Lovato, T.; Dieckow, J.; Zanatta, J.A.; Mielniczuk, J. A method for estimating coefficients of soil organic matter dynamics based on long-term experiments. Soil and Tillage Research, v. 91, n.1-2, p. 217-226, 2006a. https://doi. org/10.1016/j.still.2005.12.006.

Bayer, C.; Martin Neto, L.; Mielniczuk, J.; Pavinato, A.; Dieckow, J. Carbon sequestration in two Brazilian Cerrado soils under no-till. Soil and Tillage Research, v. 86, n.2, p. 237-245, 2006b. https:// doi.org/10.1016/j.still.2005.02.023.

Bayer, C.; Mielniczuk, J. Características químicas do solo afetadas por métodos de preparo e sistemas de cultura. Revista Brasileira de Ciência do Solo, v. 21, n.1, p. 105-112, 1997.

Bayer, C.; Mielniczuk, J.; Amado, T.J.C.; Martin-Neto, L.; Fernandes, S.V. Organic matter storage in a sandy clay loam Acrisol affected by tillage and cropping systems in southern Brazil. Soil and Tillage Research, v. 54, n.1-2, p. 101-109, 2000. https://doi.org/10.1016/ S0167-1987(00)00090-8.

Campbell, C.A.; Bowren, K.E.; Schnitzer, M.; Zentner, R.P.; Townleysmith, L. Effect of crop rotations and fertilization on soil organic matter and some biochemical properties of a thick Black Chernozem. Canadian Journal of Soil Science, v. 71, n.3, p. 377 387, 1991. https://doi.org/10.4141/cjss91-036. 
Carvalho, P.C.D.; Peterson, C.A.; Nunes, P.A.D.; Martins, A.P.; DE Souza, W.; Bertolazi, V.T.; Kunrath, T.R.; De Moraes, A.; Anghinoni, I. Animal production and soil characteristics from integrated crop-livestock systems: toward sustainable intensification. Journal of Animal Science, v. 96, n.8, p. 3513-3525, 2018. https:// doi.org/10.1093/jas/sky085.

Christensen, B.T. Physical fractionation of soil and structural and functional complexity in organic matter turnover. European Journal of Soil Science, v. 52, n.2, p. 345-353, 2001. https://doi. org/10.1046/j.1365-2389.2001.00417.x.

Conceição, P.C.; Boeni, M.; Dieckow, J.; Bayer, C.; Mielniczuk, J. Fracionamento densimétrico com politungstato de sódio no estudo da proteção física da matéria orgânica em solos. Revista Brasileira de Ciência do Solo, v. 32, n.2, p. 541-549, 2008. https:// doi.org/10.1590/S0100-06832008000200009.

Conceição, P.C.; Dieckow, J.; Bayer, C. Combined role of no-tillage and cropping systems in soil carbon stocks and stabilization. Soil and Tillage Research, v. 129, p. 40-47, 2013. https://doi. org/10.1016/j.still.2013.01.006.

Debiasi, H.; Franchini, J.C. Atributos físicos do solo e produtividade da soja em sistema de integração lavoura-pecuária com braquiária e soja. Ciência Rural, v. 42, n.7, p. 1180-1186, 2012. https://doi. org/10.1590/S0103-84782012000700007.

Empresa Brasileira de Pesquisa Agropecuária - Embrapa. Manual de métodos de análise de solo. 3.ed. Rio de Janeiro: Embrapa Solos, 2011. 573p.

Ferreira, A.O.; Sá, J.C.M.; Harms, M.G.; Miara, S.; Briedis, C.; Netto, C.G.; Santos, J.B.; Canalli, L.B. Carbon balance and crop residue management in dynamic equilibrium under a no-till system in Campos Gerais. Revista Brasileira de Ciência de Solo v. 36, n.5, p. 1583-1590, 2012. https://doi.org/10.1590/S010006832012000500022.

Franzluebbers, A.J.; Stuedemann, J.A. Soil-profile distribution of organic $\mathrm{C}$ and $\mathrm{N}$ after 6 years of tillage and grazing management. European Journal of Soil Science, v. 64, n.5, p. 558-566, 2013. https://doi.org/10.1111/ejss.12057.

George, S.; Wright, D.L.; Marois, J.J. Impact of grazing on soil properties and cotton yield in an integrated crop-livestock system. Soil and Tillage Research, v. 132, p. 47-55, 2013. https:// doi.org/10.1016/j.still.2013.05.004.

Haddaway, N.R.; Hedlund, K.; Jackson, L.E.; Katterer, T.; Lugato, E.; Thomsen, I.K.; Jorgensen, H.B.; Isberg, P.E. How does tillage intensity affect soil organic carbon? A systematic review. Environmental Evidence, v. 6, article 30, 2017. https://doi. org/10.1186/s13750-017-0108-9.

Kong, A.Y.Y.; Six, J. Tracing root vs. residue carbon into soils from conventional and alternative cropping systems. Soil Science Society of America Journal, v. 74, n.4, p. 1201-1210, 2010. https://doi.org/10.2136/sssaj2009.0346.
Laroca, J.V.D.; De Souza, J.M.A.; Pires, G.C.; Pires, G.J.C.; Pacheco, L.P.; Da Silva, F.D.; Wruck, F.J.; Carneiro, M.A.C.; Siiva, L.S.; De Souza, E.D. Soil quality and soybean productivity in crop-livestock integrated system in no-tillage. Pesquisa Agropecuária Brasileira, v. 53, n.11, p. 1248-1258, 2018. https://doi.org/10.1590/s0100$204 \times 2018001100007$.

Medrado, R.D.; Carvalho, P.C.de F.; Moraes, A. de.; Rios, E. de M, Lang, C. R.; Lopes, E. C. P. Decomposição de resíduos culturais e liberação de nitrogênio para a cultura do milho. Scientia Agrária, v.12, n.2, p. 97-107, 2011. https://doi.org/10.5380/rsa. v12i2.33761.

Miguel, M.F.; Ribeiro Filho, H.M.N.; Crestani, S.; Ramos, F.R.; Genro, T.C.M. Pasture characteristics of Italian ryegrass and milk production under different management strategies. Pesquisa Agropecuária Brasileira, v. 47, n.6, p. 863-868, 2012. https://doi. org/10.1590/S0100-204X2012000600018.

Reis, C.E.S. dos; Dick, D.P.; Caldas, J. da S.; Bayer, C. Carbon sequestration in clay and silt fractions of Brazilian soils under conventional and no-tillage systems. Scientia Agrícola, v. 71, n.4, p. 292-301, 2014. https://doi.org/10.1590/0103-9016-20130234.

Sá, J.C.M.; Cerri, C.C.; Dick, W.A.; Lal, R.; Venske-filho, S.P.; Piccolo, M.C.; Feigl, B.E. Organic matter dynamics and carbon sequestration rates for a tillage chronosequence in a Brazilian Oxisol. Soil Science Society of America Journal, v. 65, n.5, p. 14861499, 2001. https://doi.org/10.2136/sssaj2001.6551486x.

Salton, J.C.; Mielniczuk, J.; Bayer, C.; Fabrício, A.C.; Macedo, M.C.M.; Broch, D.L. Teor e dinâmica do carbono no solo em sistemas de integração lavoura-pecuária. Pesquisa Agropecuária Brasileira, v. 46 , n.10, p. 1349-1356, 2011. https://doi.org/10.1590/S0100204X2011001000031.

Salvo, L.; Hernandez, J.; Ernst, O. Distribution of soil organic carbon in different size fractions, under pasture and crop rotations with conventional tillage and no-till systems. Soil and Tillage Research, v. 109, n.2, p. 116-122, 2010. https://doi.org/10.1016/j. still.2010.05.008.

Sandini, I.E.; Moraes, A.; Pelissari, A.; Neumann, M.; Falbo, M.K.; Novakowiski, J.H. Efeito residual do nitrogênio na cultura do milho no sistema de produção integração lavoura-pecuária. Ciência Rural, v. 41, n.8, p. 1315-1322, 2011. https://doi.org/10.1590/ S0103-84782011005000099.

Statsoft. Statistica (data analysis software system), version 7. Tulsa: Statsoft, 2007.

Von Lützow, M.; Kögel-Knabner, I.; Ludwig, B.; Matzner, E.; Flessa, H.; Ekschmitt, K.; Guggenberger, G.; Marschner, B.; Kalbitz, K. Stabilization mechanisms of organic matter in four temperate soils: Development and application of a conceptual model. Journal of Plant Nutrition and Soil Science, v.171, n.1, p. 111-124, 2008. https://doi.org/10.1002/jpln.200700047. 